\title{
Biological and Chemical Processes that Lead to Textile Malodour Development
}

\author{
Florence Van Herreweghen ${ }^{1}$, Caroline Amberg ${ }^{2}$, Rita Marques ${ }^{2}$ and Chris Callewaert $1, * \mathbb{C}$ \\ 1 Center for Microbial Ecology and Technology (CMET), Ghent University, Sint-Pietersnieuwstraat 33, \\ 9000 Ghent, Belgium; florence.vanherreweghen@ugent.be \\ 2 Swissatest Testmaterialien AG, Mövenstrasse 12, 9015 St. Gallen, Switzerland; \\ Caroline.amberg@swissatest.ch (C.A.); rita.marques@swissatest.ch (R.M.) \\ * Correspondence: Chris.callewaert@ugent.be
}

Received: 15 September 2020; Accepted: 30 October 2020; Published: 31 October 2020

\begin{abstract}
The development of malodour on clothing is a well-known problem with social, economic and ecological consequences. Many people still think malodour is the result of a lack of hygiene, which causes social stigma and embarrassment. Clothing is washed more frequently due to odour formation or even discarded when permastink develops. The malodour formation process is impacted by many variables and processes throughout the textile lifecycle. The contact with the skin with consequent transfer of microorganisms, volatiles and odour precursors leads to the formation of a distinctive textile microbiome and volatilome. The washing and drying processes further shape the textile microbiome and impact malodour formation. These processes are impacted by interindividual differences and fabric type as well. This review describes the current knowledge on the volatilome and microbiome of the skin, textile and washing machine, the multiple factors that determine malodour formation on textiles and points out what information is still missing.
\end{abstract}

Keywords: malodour; textile odour; permastink; skin microbiome; volatilome

\section{Introduction}

During their lifecycle, clothing items can become a source of malodour generation. This odour build-up has an effect on the daily life comfort, the life cycle of textile and the use of resources [1]. A survey by Kubota et al. [2] reported that $86 \%$ of respondents (580 women living in Tokyo) had encountered laundry malodour problems.

These unpleasant odours can originate from many different sources and the development is influenced by a number of variables (Figure 1). During the wearing process, skin bacteria attach to the clothing and selective bacterial growth is possible. Sweat, sebum and bacterial metabolites are adsorbed on the clothing through contact with the skin and can serve as precursors for malodour. This leads to the formation of a distinctive textile microbiome and volatilome, which are impacted by the fabric type, the individual and the wearing process. The collection and storing of dirty laundry, before washing, allows for a transfer of bacteria and odorous compounds between different items of clothing, from different people. 


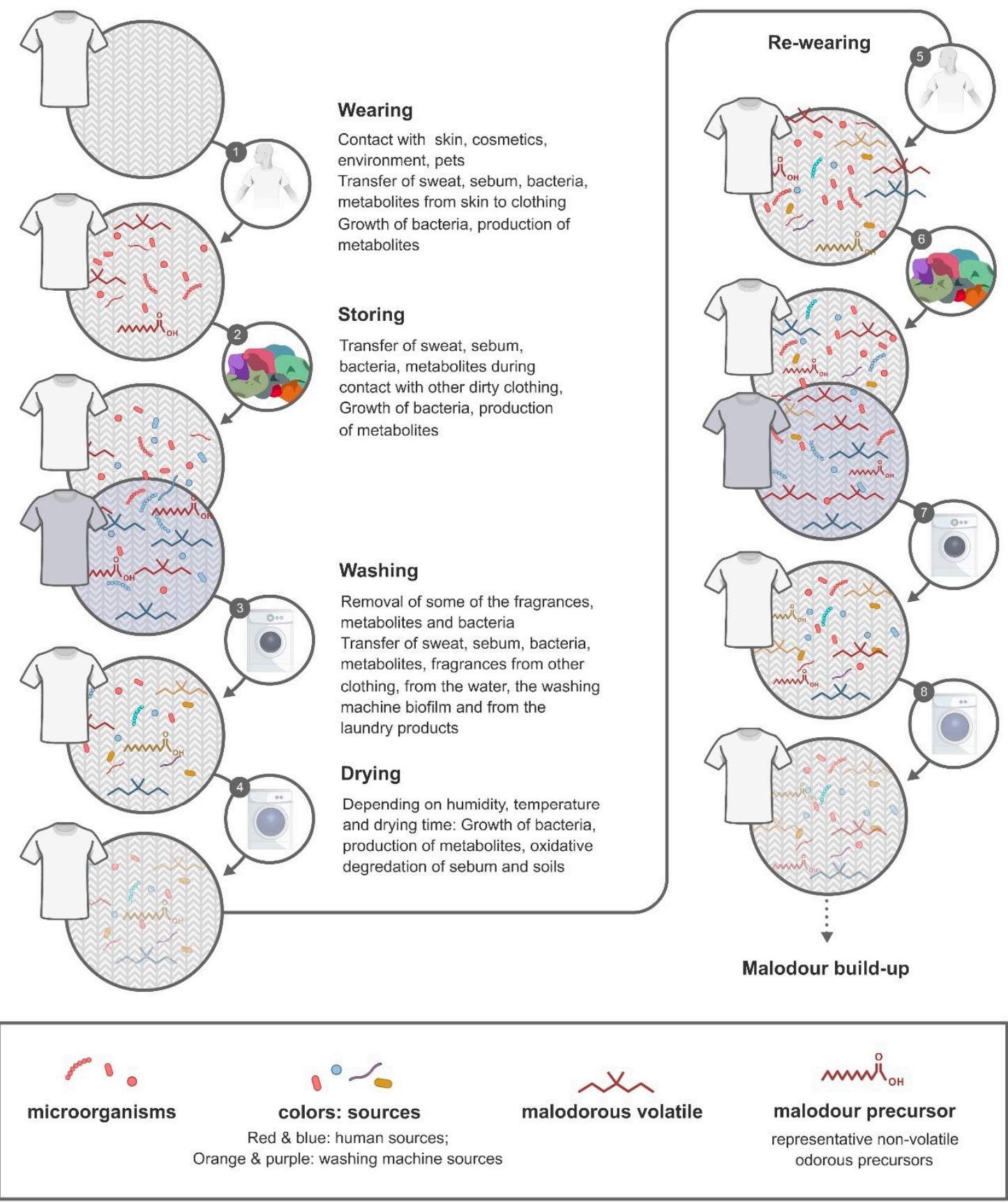

Figure 1. Schematic overview of different processes (wearing, storing, washing, drying, re-wearing) during two wear-wash-dry cycles affecting metabolites and microorganisms from different sources attaching to clothing. During the wearing (1), the clothing is in contact with the skin where a transfer of e.g., microorganisms and sebum occurs (indicated in red). When the clothing is stored before washing (2), a cross-over of these microorganisms and metabolites between clothing from another individual (indicated in blue) can take place. The washing process (3) reduces the amount of microorganisms and metabolites on the clothing, with an efficiency dependent on temperature, wash time and type of detergent. Furthermore, bacteria and metabolites present in the washing machine and in the wash water as well as fragrances and enzymes and other ingredients from the detergent/softener attach to the clothing. The effect of the drying process (4) is dependent on humidity, temperature and drying time, although relatively unstudied. In subsequent wear cycles (5) these processes are repeated and microorganisms and malodour volatiles accumulate to a situation of excessive malodour build-up or permastink. 
Laundry, the washing of clothing, has been part of human domestic life for a long time and its goal is to remove dust, dirt and stains from the textile. Next to this more visible task, the washing process should also reduce the amount of bacteria and their metabolites present on fabric. This is not only important for hygienic reasons but also to diminish textile malodour formation. By washing at higher temperatures $\left(>50^{\circ} \mathrm{C}\right.$ ), for longer periods of time or by using oxidizing compounds (such as chlorine and activated oxygen bleach), the microbial reduction is typically sufficient to obtain adequate hygiene [3-5]. Whether this is also sufficient to obtain adequate odour removal remains unclear.

Due to energy conservation measures, the temperature of household washes were reduced in recent decades, whereas the wash duration increased [4]. An increased sensitivity of many modern textiles towards higher temperatures and chemical detergents likewise changed the washing habits. Washing processes at lower temperatures $\left(\sim 30^{\circ} \mathrm{C}\right)$ with enzyme-based detergent free of oxidizing compounds are not reducing the microbial load on the fabric, but result in a microbial exchange between the microbiome in the washing machine, in the water and on the pieces of clothing [4-7]. Part of the odorants can be removed during washing, depending on fibre and individual, and can be replaced by fragrances from the laundry detergent and conditioner [8]. Reduced washing efficiency can potentially cause build-up of microorganisms and odour. This may have contributed to the increasing complaints about clothes that have a "permastink", or about a dank smell of freshly washed clothes, of the washing machines and of poorly dried washed clothes [6,9]. Little research has been done focussing on the effect of the drying conditions on malodour formation, but factors like temperature, humidity and UV light will affect the evaporation of volatiles and the growth and activity of malodour-forming bacteria $[2,6,10]$.

This article reviews the literature relating to odour formation on textile and the contributing factors. The aim of this review is to show the complexity of this multifaceted problem, to describe the variety of variables impacting this process and to point out what information is still missing.

\section{The Human Skin}

\subsection{Skin Microbiome}

One important contribution that shapes the textile microbiome is the skin microbiome, as clothes are in very close contact with the skin. In general, the skin is slightly acidic $(\mathrm{pH}= \pm 5.6)$, a bit cooler than the core body temperature $\left(\mathrm{T}= \pm 30^{\circ} \mathrm{C}\right)$, relatively salty and dry. Distinct skin sites are determined by skin thickness, folds, density of hair follicles and glands, resulting in microenvironments with specific $\mathrm{pH}$, moisture, sebum content, temperature and topography [11-13]. The microbial communities differ greatly in composition, diversity and abundance depending on these microenvironments. Moist microenvironments, such as axillae, perineum and toe webs, are occluded and higher in temperature and humidity. They have the highest bacterial counts, with up to $10^{6}$ organisms $/ \mathrm{cm}^{2}$, of which most species belong to the Staphylococcus or Corynebacterium genus or Betaproteobacteria class. Sebaceous microenvironments, on the upper body part, produces the lipid-rich sebum, which encourages the growth of lipophilic microorganisms such as Cutibacterium and Malassezia, as well as some Staphylococcus and Corynebacterium sp. Dry microenvironments are the most diverse regions with species from Betaproteobacteria class, Corynebacterium and Cutibacterium genus and Flavobacteriales order, and contain low bacterial counts $\left(10^{3}\right.$ organisms $\left./ \mathrm{cm}^{2}\right)$ [12-15].

These microenvironments not only determine community composition but also the temporal variability. Sites that are partly occluded and sebaceous, such as the auditory canal, the groin, and parts of the nose, are the most stable over time with respect to community membership and composition, whereas dry sites like the forearms, shins and hands show more variability. Temporal variability was shown to be modestly correlated with community diversity, as high diversity sites were likely to be less stable over time compared to low diversity sites [13,15-17].

Other factors influencing the microbiome are gender [18,19], geographical location [18,20], ethnicity [21], depth within the epidermis [12,19], antibiotic treatment [22], use of cosmetics [23-25], 
genetic disposition [26], age [18,25] and health status [27]. Despite the high interindividual and temporal variability, the skin microenvironment is the primary factor describing the variation in the community structure $[14,17,18]$. One good example is the armpit, where a high concentration of eccrine, apocrine and sebaceous sweat glands, hair and the occluded nature leads to the growth of high abundance of bacteria, which may be associated with malodour formation [28].

\subsection{Body Odour}

Body odour, or malodour generation on different body sites, is caused by the microbial degradation of skin secretions. Members of the skin microbiota are capable of transforming the odourless secretions from eccrine, apocrine and sebaceous glands into volatile odorous molecules [29-31]. The warm, moist and nutrient rich environment of the axillae ensures the continuous colonization by an abundant and diverse microbial population, making the axillary microenvironment a hotspot for odour formation.

The odour profile is dependent on the microbial community composition and the quality and quantity of the secretions and is thus impacted by age, gender, cosmetics use, diet, climate, stress, hygiene etc. [28,31-34]. Studies have shown that corynebacteria abundance is correlated with body malodour and that Corynebacterium tuberculostearicum, Staphylococcus hominis and Anaerococcus sp. are important actors in odour formation [28].

The odour precursors mainly come from the apocrine secretions that consist of long-chain fatty acids, fatty acids bound to amino acids, sulphur containing amino acids, vitamins and steroids. The eccrine glands are responsible for thermoregulatory sweat secretion and release a more watery electrolyte solution containing $\mathrm{Na}^{+}, \mathrm{K}^{+}, \mathrm{Ca}^{2+}, \mathrm{Mg}^{2+}, \mathrm{Cl}^{-}, \mathrm{HCO}^{-}$, lactate, urea and ammonium $[30,35,36]$.

Based on the current literature we can distinguish different microbial transformations resulting in odorous volatiles: steroid-, sulphur- and volatile fatty acids (VFA)-based malodours. Sulphurous compounds have a low olfactory threshold and contribute greatly to the axillary odour, giving it its typical onion-like and musky scent. Bacterial dipeptidases and C-S-lyases can cleave the carbon-sulphur bonds in the cysteine-based conjugates precursor (e.g., S-hydroxyalkyl-L-cystein(glycine)) resulting in the release of mercaptoalcohols, such as 3-methyl-3-mercaptohexan-1-ol [28,36-38]. Both corynebacteria and staphylococci can carry out these transformations, and studies have identified Staphylococcus hominis, Staphylococcus haemolyticus and Staphylococcus lugdunensis to be particularly efficient [39,40].

Other microbial transformations lead to the production of short-, medium-, and branched-chain volatile fatty acids, which contribute to the odour profile by evaporation or by promoting microbial growth. Lactic acid and glycerol, released from triacylglycerides, can be converted by Staphylococcus and Cutibacterium species to acetic acid and propionic acid [30,41]. Biotransformation of leucine, or other branched aliphatic amino acids, by Staphylococcus species results in isovaleric acid, an important contributor to the acidic note of axillary malodour. These amino acids are present in eccrine sweat, but may also come from bacterial degradation of proteins in apocrine secretions or keratinising epidermis. Another route to short and medium chain VFAs is through $\mathrm{N}$-acylglutamine aminoacylases activity by Corynebacterium species. This enzyme cleaves compounds such as 3-methyl-2-hexenoic acid (3M2H) and 3-hydroxy-3-methylhexanoic acids from their glutamine conjugate [29,30,42]. Corynebacterium species can also contribute to VFA-based malodour through partial degradation of methyl-branched long-chain fatty acids present in sebum. However, the share of this $\beta$-oxidation pathway in the VFA production may be less significant than previously thought, as the amount of precursor is limited as is the number of bacterial species able to carry out this $\beta$-oxidation $[29,30]$. Same goes for the biotransformation of steroids, which was previously suggested to be heavily implicated in axillary malodour, but more recent studies found very few axillary microorganisms capable of this transformation. Furthermore, $50 \%$ of the population is anosmic for these compounds [43]. 


\section{Clothing}

\subsection{Textile Volatilome}

Clothing contributes to odour intensity since secretions, skin debris, sebum, odorous volatiles and microorganisms are transferred from the body to the garment (Figure 1). It was stated by Shelley et al. [31] that odour intensity is potentially more intense in the fabric substrate than in the adjacent axillae. Dravnieks et al. [44] has discriminated between a primary odour, which originates in the axilla itself, and the secondary odour developing on the garments due to abiotic or biotic processes. UV-light, temperature and chemical reactions (e.g., due to detergent compounds, fabric softeners, enzymes) can transform substrates into odorous volatiles [43]. Microorganisms attaching on the fibres are able to use dirt or sebum compounds as substrate and generate volatiles as by-products $[6,45,46]$.

Human sebum is the major constituent of the organic soil load on textiles [47]. Some sebum components are difficult to remove by a washing process especially from hydrophobic fabrics such as polyester [48]. As a result, fatty components remain on the fabric and form a potential substrate for microbial growth and odour formation.

In general, unwashed textiles have a volatilome close to the one generated in the axilla with the predominance of short chain fatty acids, as isovaleric acid, and branched-chain fatty acids like 3-hydroxy-3-methylhexanoic acid or 3-methyl-2-hexenoic acid [46]. However, given by the distinct surface properties and functional groups, different fibre types have a selective uptake and retention of volatile substances. The adsorption of odorous volatiles is impacted by the polarity of odorant and fabric, as well as by the hydrophobicity of the fibre. Cotton is polar and sorbs aldehydes in high quantities, while polyester, due to its lower polarity, adsorbs less moisture [49,50]. On the other hand, the hydrophobic nature of polyester results in a strong adherence of fatty acids and aromatic compounds [50].

The numerous reactive sites of natural fibres (hydroxyl-groups in cellulose, amino acid side chains in wool) may also play a role in textile odour formation by offering adsorption sites for volatiles. It is conceivable that the odorous compounds are "trapped" in natural fibres and easier released from polyester [51,52]. This is in line with the study by Hammer et al. [53] where retention of isovaleric acid was lowest on polyester in comparison to cotton and wool. Recent work by Abdul-Bari et al. [54] showed that cotton sorbed greater amounts of octanoic acid compared to polyester, whereas polyester sorbed more nonenal than cotton. Despite the high absorption and affinity of octanoic acid to cotton, laundering removed more octanoic acid from cotton than from polyester. Moreover, nonenal was more effectively removed from cotton. Odour quality and intensity were judged consistently different across different fibre types. Polyester and polyester blends exhibit, in general, higher malodour intensities in comparison to cotton and wool $[45,55,56]$. The hedonic values of polyester were qualified as more negative (= more unpleasant) than cotton, with higher values for the odour characteristics "sweaty", "sour", "musty" and "ammonia" [23].

Mass and structure of fabrics have also some impact on odour formation. As expected, fabrics with a lower mass per $\mathrm{m}^{2}$ and a plain structure, exhibit lower odour intensities [55,57]. A washing process alters the volatilome of textiles and adds some compounds to the textile, such as detergent or softener ingredients, soil, volatiles and microorganisms from the washing machine or from other textiles. After washing, aldehydes are the predominant volatile compounds, whereas the low molecular weight organic acids were only found in smaller numbers on the washed laundry [6,46]. Aldehydes contributed most importantly to the overall odour of laundry extracts. A compilation of volatile compounds found on unwashed / washed textiles is presented in Table 1. 
Table 1. Odorous compounds identified on textiles unwashed after wear and/or after a household laundering process. FD = flavour dilution. Some studies show data on microorganisms and / or volatiles of clothes after wearing and before washing (= after wearing), while other studies present data on worn clothes after washing (= after washing). "Involved microorganisms" refers to microorganisms that have been linked with the production of the respective substances in the literature.

\begin{tabular}{|c|c|c|c|c|}
\hline Volatile Group & Odorous Volatiles & $\begin{array}{c}\text { Involved } \\
\text { Microorganisms }\end{array}$ & $\begin{array}{l}\text { Analysis before and/or } \\
\text { after Washing, } \\
\text { FD-value }\end{array}$ & Literature \\
\hline \multirow{13}{*}{ Fatty acids } & Ethanoic acid (acetic acid) & $\begin{array}{l}\text { Propionibacterium sp. } \\
\text { Staphylococcus sp. }\end{array}$ & after wearing & {$[41,58]$} \\
\hline & Propanoic acid & $\begin{array}{l}\text { Propionibacterium } s p \text {. } \\
\text { Staphylococcus sp. }\end{array}$ & after wearing & {$[41,58]$} \\
\hline & $\begin{array}{l}\text { 2-methylpropanoic acid } \\
\text { (isobutyric acid) }\end{array}$ & Bacillus subtilis & after wearing & [59] \\
\hline & Butanoic acid & & after wearing & [8] \\
\hline & 2-methylbutanoic acid & Bacillus subtilis & after wearing & [59] \\
\hline & $\begin{array}{l}\text { 3-methylbutanoic acid } \\
\text { (isovaleric acid) }\end{array}$ & $\begin{array}{c}\text { Bacillus subtilis } \\
\text { Staphylococcus epidermidis }\end{array}$ & $\begin{array}{c}\text { after wearing and after } \\
\text { washing }\end{array}$ & {$[6,38,43,59-62]$} \\
\hline & 3-methyl-2-hexenoic acid & $\begin{array}{l}\text { Corynebacterium sp. } \\
\text { Micrococcus sp. }\end{array}$ & after wearing & {$[42,58,60,63,64]$} \\
\hline & $\begin{array}{l}\text { 4-methyl-3-hexenoic acid } \\
\text { (4M3H) }\end{array}$ & Moraxella osloensis & after washing & {$[2,43]$} \\
\hline & 5-methyl-4-hexenoic acid & & after washing & [43] \\
\hline & $\begin{array}{l}\text { 3-methyl-3-hydroxy-hexanoic } \\
\text { acid }\end{array}$ & $\begin{array}{l}\text { Corynebacterium bovis, } \\
\text { Corynebacterium jeijeikum, } \\
\text { Corynebacterium striatum }\end{array}$ & after wearing & {$[42,60,63,64]$} \\
\hline & 6-heptenoic acid & & after washing & [43] \\
\hline & 4-methyloctanoic acid & & after washing & [6] \\
\hline & 4-ethyloctanoic acid & & after washing; FD > 256 & [6] \\
\hline \multirow{4}{*}{$\begin{array}{l}\text { Steroid } \\
\text { compounds }\end{array}$} & 5- $\alpha$-androstenol & & after wearing & [65] \\
\hline & 5 - $\alpha$-androstenone & & after wearing & [66] \\
\hline & 5 - $\alpha$-androst-2-en-17-one & $\begin{array}{l}\text { Staphylococcus } s p \text {. } \\
\text { Corunebacterium sp }\end{array}$ & after wearing and after & {$[6,38,60-62,67]$} \\
\hline & 5- $\alpha$-androst- 16 -ene- 3 -one & & after wearing & [58] \\
\hline \multirow{4}{*}{$\begin{array}{l}\text { Sulfur } \\
\text { compounds }\end{array}$} & $\begin{array}{l}\text { 3-methyl-3-sulfanyl-hexan-1-ol } \\
\text { (3M3SH) }\end{array}$ & $\begin{array}{c}\text { Staphylococcus } \\
\text { haemolyticus; } \\
\text { Staphylococcus hominis }\end{array}$ & after wearing & {$[38,39,42,60,63,64]$} \\
\hline & Dimethyl disulphides & & after washing & {$[8,68]$} \\
\hline & Dimethyl trisulphides & & after washing & {$[8,68]$} \\
\hline & Benzyl mercaptan & Corynebacterium sp. & after wearing & [39] \\
\hline \multirow{6}{*}{ Ketones } & 1-hexen-3-one & & after washing & [6] \\
\hline & 2-heptanone & & after wearing & [8] \\
\hline & 2-octanone & & after wearing & [8] \\
\hline & 1-octen-3-one & & $\begin{array}{c}\text { after wearing and after } \\
\text { washing }\end{array}$ & {$[6,67]$} \\
\hline & 2-nonanone & & after wearing & [8] \\
\hline & $\begin{array}{l}\text { Medium-chain ketones } \\
\text { (undetermined) }\end{array}$ & & & {$[10]$} \\
\hline \multirow{7}{*}{ Esters } & Ethyl-2-methylpropanoate & & after washing; FD > 256 & [6] \\
\hline & Ethyl butanoate & & $\begin{array}{l}\text { after wearing and after } \\
\text { washing; FD }>256\end{array}$ & {$[6,67]$} \\
\hline & Methyl-3-methyl-hexanoate & & after wearing & [58] \\
\hline & Methyl laurate & & after wearing & [58] \\
\hline & Methyl myristate & & after wearing & [58] \\
\hline & 2-Aminoacetophenone & & after wearing; FD > 256 & {$[6]$} \\
\hline & Diethyl phthalate & & after wearing & [58] \\
\hline \multirow{8}{*}{ Aldehydes } & Methional & & after washing & [6] \\
\hline & Hexanal & & after washing & [46] \\
\hline & (Z)-4-heptenal & & after washing; FD > 256 & [6] \\
\hline & Octanal & & after washing; FD > 256 & [6] \\
\hline & (E)-2-octenal & & $\begin{array}{l}\text { after washing } \\
\text { after washing }\end{array}$ & $\begin{array}{c}{[46]} \\
{[6]}\end{array}$ \\
\hline & Cis/trans-2-nonenal & & after wearing and after & {$[6,46]$} \\
\hline & (E,Z)-2,4-nonadienal & & after washing; FD > 256 & [6] \\
\hline & (E,Z)-2,6-nonadienal & & after washing; FD > 256 & [6] \\
\hline
\end{tabular}


Table 1. Cont.

\begin{tabular}{|c|c|c|c|c|}
\hline Volatile Group & Odorous Volatiles & $\begin{array}{c}\text { Involved } \\
\text { Microorganisms }\end{array}$ & $\begin{array}{l}\text { Analysis before and/or } \\
\text { after Washing, } \\
\text { FD-value }\end{array}$ & Literature \\
\hline & Decanal & & after washing & [43] \\
\hline & (E,E)-2,4-decadienal & & after washing & [6] \\
\hline & (E)-4,5-epoxy-E-2-decenal & & after wearing; FD > 256 & [6] \\
\hline & 4-methoxybenzaldehyde & & after washing; FD > 256 & {$[6,68]$} \\
\hline & $\begin{array}{l}\text { Medium-chain aldehydes } \\
\text { (not determined) }\end{array}$ & & & {$[10]$} \\
\hline \multirow{6}{*}{ Alcohols } & Oct-1-en-3-ol & & after washing & [67] \\
\hline & 2-Nonanol & & after wearing & [58] \\
\hline & 1-Decanol & & after washing & [68] \\
\hline & 1-Dodecanol & & after washing; FD > 256 & [68] \\
\hline & 2-Phenylethanol & & $\begin{array}{c}\text { after wearing and after } \\
\text { washing; FD }>256\end{array}$ & {$[67,68]$} \\
\hline & 2-Methoxyphenol (guaiacol) & & $\begin{array}{l}\text { after wearing and after } \\
\text { washing }\end{array}$ & {$[6,67]$} \\
\hline Others & Naphthalene & & after wearing & [67] \\
\hline
\end{tabular}

\subsection{Textile Microbiome}

The contribution of microorganisms on the generation of the secondary odour on textiles is still unclear. In the underarm region, bacteria are transferred in high numbers to the textile due to the close permanent contact, transferred via sweat. Mixed cultures of bacteria from the axilla were able to form biofilm on textiles [69]. However, axillary and textile microbiomes differ in their compositions. Even though the same main phyla Firmicutes, Actinobacteria and Proteobacteria were found on worn textiles and in the axilla, some synthetic textiles seem to promote attachment and growth of particular taxa that are underrepresented in the axillae [70]. While the axillary skin microbiome is dominated by Staphylococcus sp. and Corynebacterium sp., textile microbiome consists mainly of Staphylococcus sp., Micrococcus sp., and to a lower extent of Bacillus sp., Enterobacteriaceae, and Acinetobacter sp. Corynebacteria, key microorganisms for sweat odour formation in the axilla, could not be isolated from worn textiles $[23,55,70]$. Similarly as the axillary microbiome, the textile microbiome is rather individual in its composition. It seems that different microorganisms and microbial pathways are relevant for secondary odour generation. Alternatively, textile odour formation can be influenced by, for example, the physical and chemical attributes of the textile.

Different fibre types have different surface properties and functional groups which impact not only adsorption and retention of volatile compounds, but also bacterial attachment and growth. Several studies reveal a selective attachment of microorganisms on different fibre types. Staphylococcus sp. was enriched on more or less all fibre types [23,70,71], with Staphylococcus hominis having a high affinity to cotton [23]. Micrococcus luteus was accumulated on polyester, polyester blends and wool [23,70]. Wool promoted growth of many bacteria, such as Enhydrobacter sp., Cutibacterium sp., Staphylococcus epidermidis and Micrococcus sp. [23]. Cellulose-based fibres such as viscose or Tencel ${ }^{\mathrm{TM}}$ showed a low microbial growth potential for most axillary bacteria except for some Staphylococcus sp. [23,70]. Corynebacterium jeikeium, was not able to enrich on cotton, acrylic, wool, viscose, nylon, fleece and polyester, which is congruent with the findings that only low numbers of Corynebacterium sp. could be isolated from worn textiles [23,70].

\section{Washing Machine}

\subsection{Impact of Washing Process on Volatiles and Microorganisms}

The very essence of the laundry process is to obtain clean and fresh clothes, free from soil, dirt, pathogens and malodour. The washing process removes microorganisms and odorous volatiles, such as short chain fatty acids, from the fabrics. Detergent compounds and fragrances attach to the fibre during the washing cycle and contribute to textile odour intensity and profiles. When textiles undergo 
several wash and wear cycles, the resulting malodour has been influenced by several parameters like initial soil and microbe level of the garments, the storage environment, the washing and drying processes and the cleanliness of the washing machine (Figure 1).

Overall, the odour intensity is decreased by the laundering process [8]. Due to environmental reasons however, the washing temperature and water consumption have substantially declined in the last decades. Frequent use of low temperature cycles, with low water consumption and activated oxygen bleach (AOB)-free colour detergents, were shown to be inefficient in removing microorganisms, sebum and odorous compounds, and may contribute to the build-up of malodour on textiles and washing machines [6]. Furthermore, liquid detergents without activated oxygen bleach (AOB) have gained more popularity due to their convenience. Washing performance (soil removal) could at least partly be compensated by longer washing programmes and the use of enzymes. Unfortunately, it is not that easy for the removal of microorganisms. Honisch et al. [3] have systematically investigated the impact of temperature, time and detergent on microbial reduction of different bacterial and fungal strains on textile pieces in a household washing machine. Since microbial reduction is a synergistic result of time, chemistry, temperature and water consumption, it is not possible to assess the distinct effects of the single factors. In general, temperatures of $50{ }^{\circ} \mathrm{C}$ and above lead to a sufficient bacterial removal in household washing processes, independent from the used detergent and programme [5,72-74]. The use of AOB-containing detergents can compensate to a certain extent for lower temperatures. Fungal strains on the other hand, are more difficult to inactivate and some are rather resistant toward AOB-containing detergents [75].

Odour-removal efficiency of a washing process is fibre-dependent. Washed polyester still exhibits higher odour intensities than washed cotton or wool, without having differences in bacterial counts (total microbial counts, aerobic Corynebacterium sp.). It was shown that fatty acids, aldehydes and aromatic compounds were much easier removed from cotton than from polyester [45,54]. The higher moisture regain and hydrophilicity of cotton allows the laundry liquid to enter the fibre structure and breaks the interactions between cotton fibre and odorants. This could be a further factor for the cumulative odour build-up on polyester over multiple wash and wear cycles and could refer to the so-called "old-sweat odour", or "permastink", respectively, the 'sportswear problem' [1,23].

In two Japanese studies, 4-methyl-3-hexenoic acid (4M3H) was identified as a frequently detected odour component of washed and smelly laundry. The most prominent species found on those laundry items was Moraxella osloensis and its ability to produce 4-methyl-3-hexenoic acid was proven [2,76]. Furthermore in a recent study in German households, M. osloensis was identified as an abundant colonizer of the washing machines [77]. The precursors for the conversion into $4 \mathrm{M} 3 \mathrm{H}$ are not known and are a subject for further investigation.

Laundry habits do differ across the world. Many people still do hand washes with soap. Most European washing machines are horizontal axis machines and usually wash at a temperature of $30{ }^{\circ} \mathrm{C}$ to $60^{\circ} \mathrm{C}$, with an average temperature in the European Union of $42.7^{\circ} \mathrm{C}$ [78]. In South and North America and a lot of Asian countries, vertical axis washing machines (top loaders) are common. They run either with cold $\left(\sim 10-20^{\circ} \mathrm{C}\right)$ or hot water, while the average washing durations are shorter in the US (35 to $85 \mathrm{~min}$ for top-loaders) as compared to Europe (70 to $120 \mathrm{~min}$ for front-loaders) [79,80]. In Japan, short and cold wash cycles are used frequently and the bath water might be reused for laundry washing [2,43]. In some countries (like Belgium [7]), rainwater is collected from the roof and used as influent water.

\subsection{The Washing Machine Volatilome and Microbiome}

Washing machines provide perfect living conditions for microorganisms due to the humidity and the nutrients present. Nutrients and microorganisms are introduced through water, dirty laundry, washing machine biofilms and human handlers. The microorganisms are able to survive and thrive through biofilm formation and stagnant water. Microorganisms making up these biofilms include bacteria of the genera Acinetobacter, Bacillus, Brevundimonas, Micrococcus, Staphylococcus and Pseudomonas 
and fungi from the Candida, Fusarium, Aspergillus and Trichosporum genera [81-83]. Biofilms are typically formed in hardly accessible, wetted parts that are difficult to clean, such as the detergent drawer, the rubber door seal, the filter [6,82], inside plastic and synthetic parts of the washing machine and inside stagnant water of the washing machine. Gattlen et al. [82] sampled eleven washing machines from four countries and three continents and found that while the bacterial load (plate counting) was in the same range, the bacterial composition differed greatly between washing machines. Different laundry habits across the world also impact the biofilm composition. Other factors impacting the washing machine microbiome are influent water, clothing, soils, bacterial exchange, climate, as well as number and age of household members.

Mild washing conditions may result in an enrichment of opportunistic and/or antibiotic-resistant pathogens in washing machine biofilms as well as in increasing malodour formation [3,82-86]. Leaving washed laundry in the washing machine overnight, leads to an enrichment of the biofilm-related Pseudomonas sp. on washed clothes [7].

Stagnant water in tubing or inside the washing machine is a source for bacterial and fungal growth, and consequently odour formation [67]. A wide range of volatiles, such as 1,3-dioxanes, 1,3-dioxolanes, alkyl sulphides, geosmin, 2-methyl isoborneol, trans-2-cis-6-nonadienal, 2,3,6- trichloroanisole, 2-isopropyl-3-methoxypyrazine, thiophene, dimethyl sulphide, dimethyl disulphide and carbon disulphide, have been identified as off-odours in influent and effluent water streams [67].

Stapleton and Dean [66] investigated the possible impact of washing machine malodour on overall textile malodour and propose that washing machine malodour compounds contribute to a high extent to the overall textile malodour. Volatile compounds as well as bacteria are probably transferred from contaminated washing machines to laundry fabrics. This is, for instance, sometimes noticed by a typical musty odour when clothes are left in humid conditions in the washing machine after laundering.

To prevent biofilm build-up and associated malodours, most washing machine producers advise a frequent maintenance wash, with high temperatures and a bleaching agent. Some newer machines also include special treatments that are advertised to improve removal of microorganisms and malodour from both clothing and washing machines: for example, by using silver ions (Samsung), steam (Whirlpool) and even ultrasonic waves (Sanyo). However, studies critically evaluating these approaches have not yet been performed and actual efficacy remains to be seen.

\section{Factors that Determine Malodour Formation}

One important factor is the microbiome. Selective enrichment of microorganisms on clothing textiles and in washing machines are important reasons for textile malodour formation. Micrococcus sp. [29,70] and Moraxella sp. [76] have already been identified and linked. Other microbiota will likely play an important role, but further research is needed to identify them. Unlike the composition of the microbial community, the microbial load does not seem to be a determining factor $[45,55,87]$. As a result, antimicrobial coatings on textile have been investigated as a way to prevent odour formation. However, it was shown in several studies that antimicrobial coatings do not necessarily lead to an odour decrease $[60,88]$, and they could affect the skin microbiome (unpublished data).

Another contributing factor is metabolite build-up in clothes and washing machines. The metabolite load in clothing textiles can increase over time, as microbial and environmental degradation of hydrophobic apocrine secretions, sebaceous secretions, skin desquamations and other human sources, can adhere and bind to clothes which leads to a build-up of metabolite precursors [89]. It is known that dry and freshly washed permastink clothes emit a direct malodour when ironed, which can be explained by the release of covalently bound hydrophobic molecules that are released with the heat. Additionally, both type and quantity of metabolites can differ greatly between individuals. A study by Martin et al. [26] showed that an alteration in the human ABCC11 gene, which is prominent among Asian people, impacted apocrine sweat secretions and thus metabolite build-up. Other interindividual dissimilarities, among which gender, body mass index, hygiene habits, ethnicity, nutritional and intercultural differences likely play a role in metabolite build-up in clothes. The identity 
and origin of these metabolites are nonetheless still the subject of future studies. Laundry detergent ingredients should focus on removal of those hard-to-remove metabolites. Incorporation of activated carbon, zeolites, and cyclodextrins [90] have been suggested.

The fibre type is an important aspect in the malodour build-up process, as different fibres will react differently to the wear, wash and dry processes during the textile life cycle. Synthetic fibres, such as polyester, nylon and polyamide, are apolar, have hydrophobic functional groups and can adhere lipids and fatty acid molecules well [50]. Malodour precursors are likely more easily removed from natural fibres in the laundry process. The large interstitial surface and absorbing capacity of natural fibres can additionally contribute to a differential odour release during wear. A promising solution might be the modification of surface properties of synthetic fibres such as the application of hydrophilic coatings [53]. However, optimal solutions should be found for each textile type and should also cover fibre blends, re-used and up-cycled fibres.

The washing process has a big influence in odour removal, which is strongly influenced by time, temperature, detergent type/ingredients, wash load, fabric softeners, and frequency of washing. Due to the growing use of non-bleach containing liquid detergents and the ongoing trend towards cold-wash conditions, hygiene performances of washing processes have decreased. Only in hospital settings, it is still preferred to use bleach-based detergents and concomitant high temperatures [91-95]. Additionally, it was found that lipase-containing detergent led to a higher perceived odour intensity and qualitative differences in aldehyde compounds, as compared to the same detergent without lipase [6]. Likewise, the use of fabric softeners seems to increase the malodour problem on polyester and synthetic blends, whereas there is no odour impact of fabric softener on cotton fabrics [96]. An optimal program and detergent combination and a monthly washing machine cleaning measure can lead to an improved laundry efficacy.

The drying conditions additionally play an important role in the load of microorganisms and metabolites present on the dried textiles. Humidity after washing and during drying is an important contributing factor. Fast drying and tumble drying were found to be effective in decreasing the microbial load, while slow drying resulted in a higher microbial load on textiles $[6,97,98]$. Laundered clothes that are left in humid conditions are known to form immanent malodours. Moreover, drying outdoors and in sunlight seems to have a positive impact in reducing microbial load and malodour [98]. The UVB $(\sim 310 \mathrm{~nm})$ in natural sunlight is known to reduce the fungal load [99] and likely other microbiota in clothes. UVB light generates oxidative free radicals that can actively attack macromolecules such as lipids and sweat secretions [100]. Under these circumstances, covalently bound metabolites on textiles can be released from their permanent position. As a practical example, commercial washing machines are available on the market that incorporate UV light into their drum. A steady and fast drying is advised, preferably outdoors and in sunlight, to prevent malodour formation.

\section{Conclusions}

In this review we combined the current knowledge on different aspects and impacting factors on textile malodour formation and build-up.

There is a clear lack of understanding of how the microbiome impacts malodour formation on clothes and in washing machines. Not only a qualitative description of bacterial factors, by means of sequencing technology, but also the activity of the bacteria by means of metatranscriptomics, and the involved genes and the pathways leading to malodour, by means of metagenome prediction from short read technology and/or metagenomic analysis from whole genome sequencing. In addition, it is important to learn more about the involvement and influence of fungi, archaea and micro-eukaryotes in clothing and malodour development. Studies have mainly identified malodorous volatiles using GC/MS. It would be interesting to perform untargeted metabolomics (with LC/MS), to identify the larger molecules present on clothes and in washing machines, in order to identify the precursors and the possible biological pathways. 
The current knowledge mainly comes from smaller studies and experiments, focussing on one or few aspects of the malodour formation process. While these results offer useful and important findings, the conclusions are limited due to their limited scope. There is a need for larger scale studies focusing both the composition and quantity of the microbiome and volatilome throughout the entire wear-wash-dry cycle of clothing. Taking into account the interindividual differences as well as different fibre types, different wearing, washing and drying conditions, can offer more insights into the different factors interacting and impacting the malodour formation process. These insights are much needed to open up opportunities for the development of new techniques and approaches to combat clothing and laundry malodour formation.

Author Contributions: C.C. had the idea for the review article. All authors contributed to the conceptualisation, literature study and the first draft of the manuscript. All authors commented on previous versions of the manuscript. All authors have read and agreed to the published version of the manuscript.

Funding: This research received no external funding.

Conflicts of Interest: Van Herreweghen reports grants from Givaudan UK Ltd., outside the submitted work. Amberg has nothing to disclose. Marques has nothing to disclose. Callewaert reports a research grant from Givaudan UK Ltd., and other from Visto.bio, outside the submitted work.

\section{References}

1. Klepp, I.G.; Buck, M.; Laitala, K.; Kjeldsberg, M. What's the problem? Odor-control and the smell of sweat in sportswear. Fash. Pract. 2016, 8, 296-317. [CrossRef]

2. Kubota, H.; Mitani, A.; Niwano, Y.; Takeuchi, K.; Tanaka, A.; Yamaguchi, N.; Kawamura, Y.; Hitomi, J. Moraxella species are primarily responsible for generating malodor in laundry. Appl. Environ. Microbiol. 2012, 78, 3317-3324. [CrossRef] [PubMed]

3. Honisch, M.; Stamminger, R.; Bockmuhl, D.P. Impact of wash cycle time, temperature and detergent formulation on the hygiene effectiveness of domestic laundering. J. Appl. Microbiol. 2014, 117, 1787-1797. [CrossRef] [PubMed]

4. Bockmuhl, D.P.; Schages, J.; Rehberg, L. Laundry and textile hygiene in healthcare and beyond. Microb. Cell 2019, 6, 299-306. [CrossRef] [PubMed]

5. Bockmuhl, D.P. Laundry hygiene-how to get more than clean. J. Appl. Microbiol. 2017, 122, $1124-1133$. [CrossRef] [PubMed]

6. Munk, S.; Johansen, C.; Stahnke, L.H.; Adler-Nissen, J. Microbial survival and odor in laundry. J. Surfactants Deterg. 2001, 4, 385-394. [CrossRef]

7. Callewaert, C.; Van Nevel, S.; Kerckhof, F.M.; Granitsiotis, M.S.; Boon, N. Bacterial exchange in household washing machines. Front. Microbiol. 2015, 6, 1381. [CrossRef] [PubMed]

8. Denawaka, C.J.; Fowlis, I.A.; Dean, J.R. Source, impact and removal of malodour from soiled clothing. J. Chromatogr. A 2016, 1438, 216-225. [CrossRef]

9. McQueen, R.H.; Keelan, M.; Xu, Y.; Mah, T. In vivo assessment of odour retention in an antimicrobial silver chloride-treated polyester textile. J. Text. Instit. 2013, 104, 108-117. [CrossRef]

10. Nagoh, Y.; Tobe, S.; Watanabe, T.; Mukaiyama, T. Analysis of odorants produced from indoor drying laundries and effects of enzyme for preventing malodor generation. Tenside Surf. Det. 2005, 42, 7-12. [CrossRef]

11. Gallo, R.L. Human skin is the largest epithelial surface for interaction with microbes. J. Investig. Dermatol. 2017, 137, 1213-1214. [CrossRef] [PubMed]

12. Grice, E.A.; Segre, J.A. The skin microbiome. Nat. Rev. Microbiol. 2011, 9, 244-253. [CrossRef] [PubMed]

13. Grice, E.A.; Kong, H.H.; Conlan, S.; Deming, C.B.; Davis, J.; Young, A.C.; Program, N.C.S.; Bouffard, G.G.; Blakesley, R.W.; Murray, P.R.; et al. Topographical and temporal diversity of the human skin microbiome. Science (NY) 2009, 324, 1190-1192. [CrossRef] [PubMed]

14. Costello, E.K.; Lauber, C.L.; Hamady, M.; Fierer, N.; Gordon, J.I.; Knight, R. Bacterial community variation in human body habitats across space and time. Science (NY) 2009, 326, 1694-1697. [CrossRef]

15. Cundell, A.M. Microbial ecology of the human skin. Microb. Ecol. 2018, 76, 113-120. [CrossRef]

16. Oh, J.; Byrd, A.L.; Park, M.; Program, N.C.S.; Kong, H.H.; Segre, J.A. Temporal stability of the human skin microbiome. Cell 2016, 165, 854-866. [CrossRef] 
17. Oh, J.; Byrd, A.L.; Deming, C.; Conlan, S.; Program, N.C.S.; Kong, H.H.; Segre, J.A. Biogeography and individuality shape function in the human skin metagenome. Nature 2014, 514, 59-64. [CrossRef]

18. Ying, S.; Zeng, D.N.; Chi, L.; Tan, Y.; Galzote, C.; Cardona, C.; Lax, S.; Gilbert, J.; Quan, Z.X. The influence of age and gender on skin-associated microbial communities in urban and rural human populations. PLOS ONE 2015, 10, e0141842. [CrossRef]

19. Zeeuwen, P.L.; Boekhorst, J.; van den Bogaard, E.H.; de Koning, H.D.; van de Kerkhof, P.M.; Saulnier, D.M.; van Swam, I.I.; van Hijum, S.A.; Kleerebezem, M.; Schalkwijk, J.; et al. Microbiome dynamics of human epidermis following skin barrier disruption. Genome Biol. 2012, 13, R101. [CrossRef]

20. McCall, L.I.; Callewaert, C.; Zhu, Q.; Song, S.J.; Bouslimani, A.; Minich, J.J.; Ernst, M.; Ruiz-Calderon, J.F.; Cavallin, H.; Pereira, H.S.; et al. Home chemical and microbial transitions across urbanization. Nat. Microbiol. 2020, 5, 108-115. [CrossRef]

21. Harker, M.; Carvell, A.M.; Marti, V.P.; Riazanskaia, S.; Kelso, H.; Taylor, D.; Grimshaw, S.; Arnold, D.S.; Zillmer, R.; Shaw, J.; et al. Functional characterisation of a snp in the abcc11 allele-Effects on axillary skin metabolism, odour generation and associated behaviours. J. Dermatol. Sci. 2014, 73, 23-30. [CrossRef] [PubMed]

22. Claesen, J.S.J.; Ramos, S.F.; Kurita, K.L.; Byrd, A.L.; Aksenov, A.A.; Melnik, A.V.; Wong, W.R.; Wang, S.; Hernandez, R.D.; Donia, M.S.; et al. Cutibacterium acnesantibiotic production shapes niche competition in the human skin microbiome. BioRxiv Prepr. 2019, 1-13. [CrossRef]

23. Callewaert, C.; De Maeseneire, E.; Kerckhof, F.M.; Verliefde, A.; Van de Wiele, T.; Boon, N. Microbial odor profile of polyester and cotton clothes after a fitness session. Appl. Environ. Microbiol. 2014, 80, 6611-6619. [CrossRef] [PubMed]

24. Bouslimani, A.; da Silva, R.; Kosciolek, T.; Janssen, S.; Callewaert, C.; Amir, A.; Dorrestein, K.; Melnik, A.V.; Zaramela, L.S.; Kim, J.N.; et al. The impact of skin care products on skin chemistry and microbiome dynamics. BMC Biol. 2019, 17, 47. [CrossRef] [PubMed]

25. Li, M.; Budding, A.E.; van der Lugt-Degen, M.; Du-Thumm, L.; Vandeven, M.; Fan, A. The influence of age, gender and race/ethnicity on the composition of the human axillary microbiome. Int. J. Cosmet. Sci. 2019, 41, 371-377. [CrossRef] [PubMed]

26. Martin, A.; Saathoff, M.; Kuhn, F.; Max, H.; Terstegen, L.; Natsch, A. A functional abcc11 allele is essential in the biochemical formation of human axillary odor. J. Investig. Dermatol. 2010, 130, 529-540. [CrossRef]

27. Ellis, A.; Billings, S.D.; Khanna, U.; Warren, C.B.; Piliang, M.; Vij, A.; Ko, J.S.; Bergfeld, W.F.; Fernandez, A.P. Diagnoses of hospitalized patients with skin abnormalities prompting biopsy by consulting dermatologists: A 3-year review from a tertiary care center. J. Cutan. Pathol. 2020, 47, 346-356. [CrossRef]

28. Troccaz, M.; Gaia, N.; Beccucci, S.; Schrenzel, J.; Cayeux, I.; Starkenmann, C.; Lazarevic, V. Mapping axillary microbiota responsible for body odours using a culture-independent approach. Microbiome 2015, 3, 3. [CrossRef]

29. James, A.G.; Austin, C.J.; Cox, D.S.; Taylor, D.; Calvert, R. Microbiological and biochemical origins of human axillary odour. FEMS Microbiol. Ecol. 2013, 83, 527-540. [CrossRef]

30. Fredrich, E.; Barzantny, H.; Brune, I.; Tauch, A. Daily battle against body odor: Towards the activity of the axillary microbiota. Trends Microbiol. 2013, 21, 305-312. [CrossRef]

31. Shelley, W.B.; Hurley, H.J., Jr. The physiology of the human axillary apocrine sweat gland. J. Investig. Dermatol. 1953, 20, 285-297. [CrossRef] [PubMed]

32. Holland, K.T.; Bojar, R.A. Cosmetics: What is their influence on the skin microflora? Am. J. Clin. Dermatol. 2002, 3, 445-449. [CrossRef] [PubMed]

33. Choudhry, R.; Hodgins, M.B.; Van der Kwast, T.H.; Brinkmann, A.O.; Boersma, W.J. Localization of androgen receptors in human skin by immunohistochemistry: Implications for the hormonal regulation of hair growth, sebaceous glands and sweat glands. J. Endocrinol. 1992, 133, 467-475. [CrossRef]

34. Toyoda, Y.; Sakurai, A.; Mitani, Y.; Nakashima, M.; Yoshiura, K.; Nakagawa, H.; Sakai, Y.; Ota, I.; Lezhava, A.; Hayashizaki, Y.; et al. Earwax, osmidrosis, and breast cancer: Why does one snp (538g>a) in the human abc transporter abcc11 gene determine earwax type? FASEB J. Off. Publ. Fed. Am. Soc. Exp. Biol. 2009, 23, 2001-2013. [CrossRef]

35. Noel, F.; Pierard-Franchimont, C.; Pierard, G.E.; Quatresooz, P. Sweaty skin, background and assessments. Int. J. Dermatol. 2012, 51, 647-655. [CrossRef] 
36. Wilke, K.; Martin, A.; Terstegen, L.; Biel, S.S. A short history of sweat gland biology. Int. J. Cosmet. Sci. 2007, 29, 169-179. [CrossRef]

37. Emter, R.; Natsch, A. The sequential action of a dipeptidase and a beta-lyase is required for the release of the human body odorant 3-methyl-3-sulfanylhexan-1-ol from a secreted cys-gly-(s) conjugate by corynebacteria. J. Biol. Chem. 2008, 283, 20645-20652. [CrossRef]

38. Troccaz, M.; Starkenmann, C.; Niclass, Y.; van de Waal, M.; Clark, A.J. 3-methyl-3-sulfanylhexan-1-ol as a major descriptor for the human axilla-sweat odour profile. Chem. Biodivers. 2004, 1, 1022-1035. [CrossRef]

39. Bawdon, D.; Cox, D.S.; Ashford, D.; James, A.G.; Thomas, G.H. Identification of axillary staphylococcus sp. Involved in the production of the malodorous thioalcohol 3-methyl-3-sufanylhexan-1-ol. FEMS Microbiol. Lett. 2015, 362, fnv111. [CrossRef] [PubMed]

40. Minhas, G.S.; Bawdon, D.; Herman, R.; Rudden, M.; Stone, A.P.; James, A.G.; Thomas, G.H.; Newstead, S. Structural basis of malodour precursor transport in the human axilla. eLife 2018, 7, e34995. [CrossRef] [PubMed]

41. James, A.G.; Hyliands, D.; Johnston, H. Generation of volatile fatty acids by axillary bacteria. Int. J. Cosmet. Sci. 2004, 26, 149-156. [CrossRef] [PubMed]

42. Natsch, A.; Gfeller, H.; Gygax, P.; Schmid, J.; Acuna, G. A specific bacterial aminoacylase cleaves odorant precursors secreted in the human axilla. J. Biol. Chem. 2003, 278, 5718-5727. [CrossRef] [PubMed]

43. Takeuchi, K.; Yabuki, M.; Hasegawa, Y. Review of odorants in human axillary odour and laundry malodour: The importance of branched c7 chain analogues in malodours perceived by humans. Flavour Fragr. J. 2013, 28, 223-230. [CrossRef]

44. Dravnieks, A.; Krotoszynski, B.K.; Lieb, W.E.; Jungermann, E. Influence of an antibacterial soap on various effluents from axillae. J. Soc. Cosmet. Chem. 1968, 19, 611-626.

45. McQueen, H.R.; Harynuk, J.J.; Wismer, V.W.; Keelan, M.; Xu, Y.; Paulina, A. Axillary odour build-up in knit fabrics following multiple use cycles. Int. J. Cloth. Sci. Technol. 2014, 26, 274-290. [CrossRef]

46. Chung, H.; Seok, H.J. Populations of malodor-forming bacteria and identification of volatile components in triolein-soiled cotton fabric. Fibers Polym. 2012, 13, 740-747. [CrossRef]

47. Chi, Y.S.; Obendorf, S.K. Aging of oily soils on textile materials: A literature review. J. Surf. Deterg. 1998, 1, 407-418. [CrossRef]

48. Bowers, C.A.; Chantrey, G. Factors controlling soiling of white polyestercotton fabrics: Part I: Laboratory studies. Text. Res. J. 1969, 39, 1-11. [CrossRef]

49. Yao, L.; Laing, R.M.; Bremer, P.J.; Silcock, P.J.; Leus, M.J. Measuring textile adsorption of body odor compounds using proton-transfer-reaction mass spectrometry. Text. Res. J. 2015, 85, 1817-1826. [CrossRef]

50. Prada, P.A.; Curran, A.M.; Furton, K.G. The evaluation of human hand odor volatiles on various textiles: A comparison between contact and noncontact sampling methods. J. Forensic Sci. 2011, 56, 866-881. [CrossRef]

51. Obendorf, S.K.; Webb, J.J. Detergency study-Distribution of natural soils on shirt collars. Text. Res. J. 1987, 57, 557-563. [CrossRef]

52. Obendorf, S.K.; Namaste, Y.M.N.; Durnam, D.J. A microscopical study of residual oily soil distribution on fabrics of varying fiber content. Text. Res. J. 1983, 53, 375-383. [CrossRef]

53. Hammer, T.R.; Berner-Dannenmann, N.; Hoefer, D. Quantitative and sensory evaluation of malodour retention of fibre types by use of artificial skin, sweat and radiolabelled isovaleric acid. Flavour Fragr. J. 2013, 28, 238-244. [CrossRef]

54. Abdul-Bari, M.M.; McQueen, R.H.; Nguyen, H.; Wismer, W.V.; de la Mata, A.P.; Harynuk, J.J. Synthetic clothing and the problem with odor: Comparison of nylon and polyester fabrics. Cloth. Text. Res. J. 2018, 36, 251-266. [CrossRef]

55. McQueen, R.H.; Laing, R.M.; Brooks, H.J.L.; Niven, B.E. Odor intensity in apparel fabrics and the link with bacterial populations. Text. Res. J. 2007, 77, 449-456. [CrossRef]

56. Wang, J.; Lu, X.; Wang, J.; Wang, X. Quantitative and sensory evaluation of odor retention on polyester wool blends. Text. Res. J. 2018, 89, 2729-2738. [CrossRef]

57. Rathinamoorthy, R.; Thilagavathi, G. Optimisation of process conditions of cotton fabric treatment with terminalia chebula extract for antibacterial application. Indian J. Fibre Text. 2013, 38, 293-303.

58. Rathinamoorthy, R.; Thilagavathi, G. Gc-ms analysis of worn textile for odour formation. Fibers Polym. 2016, 17, 917-924. [CrossRef] 
59. Ara, K.; Hama, M.; Akiba, S.; Koike, K.; Okisaka, K.; Hagura, T.; Kamiya, T.; Tomita, F. Foot odor due to microbial metabolism and its control. Can. J. Microbiol. 2006, 52, 357-364. [CrossRef]

60. Obendorf, S.K.; Kim, J.; Koniz, R.F. Measurement of odor development due to bacterial action on antimicrobial polyester fabrics. Aatcc Rev. 2007, 7, 35-40.

61. Dumas, E.R.; Michaud, A.E.; Bergeron, C.; Lafrance, J.L.; Mortillo, S.; Gafner, S. Deodorant effects of a supercritical hops extract: Antibacterial activity against corynebacterium xerosis and staphylococcus epidermidis and efficacy testing of a hops/zinc ricinoleate stick in humans through the sensory evaluation of axillary deodorancy. J. Cosmet. Dermatol. 2009, 8, 197-204. [CrossRef]

62. Gower, D.B.; Mallet, A.I.; Watkins, W.J.; Wallace, L.M.; Calame, J.P. Capillary gas chromatography with chemical ionization negative ion mass spectrometry in the identification of odorous steroids formed in metabolic studies of the sulphates of androsterone, dha and 5 alpha-androst-16-en-3 beta-ol with human axillary bacterial isolates. J. Steroid Biochem. 1997, 63, 81-89.

63. Natsch, A.; Gfeller, H.; Gygax, P.; Schmid, J. Isolation of a bacterial enzyme releasing axillary malodor and its use as a screening target for novel deodorant formulations. Int. J. Cosmet. Sci. 2005, 27, 115-122. [CrossRef] [PubMed]

64. Dayan, C.L.B.N. Corynebacterium species and their role in the generation of human malodor. In Innate Immune System of Skin and Oral Mucosa: Properties and Impact in Pharmaceutics, Cosmetics, and Personal Care Products; Wertz, N.D.P.W., Ed.; John Wiley \& Sons: Hoboken, NJ, USA, 2011.

65. Brooksbank, B.W.; Brown, R.; Gustafsson, J.A. The detection of 5alpha-androst-16-en-3alpha-ol in human male axillary sweat. Experientia 1974, 30, 864-865. [CrossRef] [PubMed]

66. Claus, R.; Alsing, W. Occurrence of 5alpha-androst-16en-3-one, a boar pheromone, in man and its relationship to testosterone. J. Endocrinol. 1976, 68, 483-484. [CrossRef] [PubMed]

67. Hammond, C.J. Chemical composition of household malodours-An overview. Flavour Fragr. J. 2013, 28, 251-261. [CrossRef]

68. Stapleton, K.; Dean, J.R. A preliminary identification and determination of characteristic volatile organic compounds from cotton, polyester and terry-towel by headspace solid phase microextraction gas chromatography-mass spectrometry. J. Chromatogr. A 2013, 1295, 147-151. [CrossRef]

69. Teufel, L.; Redl, B. Improved methods for the investigation of the interaction between textiles and microorganisms. Lenzing. Ber. 2006, 85, 54-60.

70. Teufel, L.; Pipal, A.; Schuster, K.C.; Staudinger, T.; Redl, B. Material-dependent growth of human skin bacteria on textiles investigated using challenge tests and DNA genotyping. J. Appl. Microbiol. 2010, 108, 450-461. [CrossRef]

71. Takashima, M.; Shirai, F.; Sageshima, M.; Ikeda, N.; Okamoto, Y.; Dohi, Y. Distinctive bacteria-binding property of cloth materials. Am. J. Infect. Control 2004, 32, 27-30. [CrossRef]

72. Lucassen, R.; Merettig, N.; Bockmühl, D.P. Antimicrobial efficacy of hygiene rinsers under consumer-related conditions. Tenside Surfactant Deterg. 2013, 50, 259-262. [CrossRef]

73. Bellante, S.; Engel, A.; Hatice, T.; Neumann, A.; Okyay, G.; Vossebein, L. Hygienische aufbereitung von textilien in privathaushalten-eine studie aus der praxis. Hyg. Med. 2011, 36, 300-305.

74. Bloomfield, S.F.; Exner, M.; Signorelli, C.; Scott, E.A. Effectiveness of Laundering Processes Used in Domestic (Home) Settings October 2013; International Science Forum on Home Hygien: Somerset, UK, 2013; pp. 1-62.

75. Hammer, T.R.; Mucha, H.; Hoefer, D. Infection risk by dermatophytes during storage and after domestic laundry and their temperature-dependent inactivation. Mycopathologia 2011, 171, 43-49. [CrossRef] [PubMed]

76. Goto, T.; Hirakawa, H.; Morita, Y.; Tomida, J.; Sato, J.; Matsumura, Y.; Mitani, A.; Niwano, Y.; Takeuchi, K.; Kubota, H.; et al. Complete genome sequence of moraxella osloensis strain kmc41, a producer of 4-methyl-3-hexenoic acid, a major malodor compound in laundry. Genome Announc. 2016, 4. [CrossRef]

77. Jacksch, S.; Thota, J.; Shetty, S.; Smidt, H.; Schnell, S.; Egert, M. Metagenomic analysis of regularly microwave-treated and untreated domestic kitchen sponges. Microorganisms 2020, 8, 736. [CrossRef]

78. International Association for Soaps, Detergents and Maintenance Products. Pan-European Consumer Habits Survey 2017: Perceptions of Cleanliness and Hygiene-Cleaning Habits, Sustainability and Safety; International Association for Soaps, Detergents and Maintenance Products: Brussels, Belgium, 2017.

79. Meredith, C. How Long Does a Washing Machine Take?-Cycle Times \& More. Available online: https: //blog.bellinghamelectric.com/ (accessed on 5 June 2020).

80. Kimberly, J. Laundry Tips That Will Save You Time. Available online: https://www.consumerreports.org/ (accessed on 5 June 2020). 
81. Nix, I.D.; Frontzek, A.; Bockmühl, D.P. Characterization of microbial communitiesin household washing machines. Tenside Surfactant Deterg. 2015, 52, 432-440. [CrossRef]

82. Gattlen, J.; Amberg, C.; Zinn, M.; Mauclaire, L. Biofilms isolated from washing machines from three continents and their tolerance to a standard detergent. Biofouling 2010, 26, 873-882. [CrossRef]

83. Babic, M.N.; Zalar, P.; Zenko, B.; Schroers, H.J.; Dzeroski, S.; Gunde-Cimerman, N. Candida and fusarium species known as opportunistic human pathogens from customer-accessible parts of residential washing machines. Fungal Biol. 2015, 119, 95-113. [CrossRef] [PubMed]

84. Terpstra, M.J. The correlation between sustainable development and home hygiene. Am. J. Infect. Control 2001, 29, 211-217. [CrossRef] [PubMed]

85. Schmithausen, R.M.; Sib, E.; Exner, M.; Hack, S.; Rosing, C.; Ciorba, P.; Bierbaum, G.; Savin, M.; Bloomfield, S.F.; Kaase, M.; et al. The washing machine as a reservoir for transmission of extended-spectrum-beta-lactamase (ctx-m-15)-producing klebsiella oxytoca st201 to newborns. Appl. Environ. Microbiol. 2019, 85. [CrossRef]

86. Boonstra, M.B.; Spijkerman, D.C.M.; Voor, A.F.; van der Laan, R.J.; Bode, L.G.M.; van Vianen, W.; Klaassen, C.H.W.; Vos, M.C.; Severin, J.A. An outbreak of st307 extended-spectrum beta-lactamase (esbl)-producing klebsiella pneumoniae in a rehabilitation center: An unusual source and route of transmission. Inf. Control Hosp. Epidemiol. 2020, 41, 31-36. [CrossRef] [PubMed]

87. McQueen, R.H.; Laing, R.M.; Wilson, C.A.; Niven, B.E.; Nelahunty, C.M. Odor retention on apparel fabrics: Development of test methods for sensory detection. Text. Res. J. 2007, 77, 642-652. [CrossRef]

88. Xu, Y.; McQueen, R.; Wismer, W. A preliminary study on the collection and detection of axillary odour within textiles. J. Text. Appar. Technol. Manag. 2013, 8, 1-13.

89. Krifa, M.; Rajaganesh, S.; Fahy, W. Perspectives on textile cleanliness-Detecting human sebum residues on worn clothing. Text. Res. J. 2019, 89, 5226-5237. [CrossRef]

90. McQueen, R.H.; Vaezafshar, S. Odor in textiles: A review of evaluation methods, fabric characteristics, and odor control technologies. Text. Res. J. 2020, 90, 1157-1173. [CrossRef]

91. Bloomfield, S.F. Preventing infectious disease in the domestic setting: A risk-based approach. Am. J. Infect. Control 2001, 29, 207-210. [CrossRef]

92. Fijan, S.; Sostar-Turk, S.; Cencic, A. Implementing hygiene monitoring systems in hospital laundries in order to reduce microbial contamination of hospital textiles. J. Hosp. Inf. 2005, 61, 30-38. [CrossRef]

93. Fijan, S.; Koren, S.; Cencic, A.; Sostar-Turk, S. Antimicrobial disinfection effect of a laundering procedure for hospital textiles against various indicator bacteria and fungi using different substrates for simulating human excrements. Diagn. Microbiol. Inf. Dis. 2007, 57, 251-257. [CrossRef]

94. Nordstrom, J.M. Evaluation of the Occurrence and Risk of Microbes in Laundry and Laundry-Associated Surfaces; The University of Arizona: Tucson, Arizona, 2009.

95. Patel, S.N.; Murray-Leonard, J.; Wilson, A.P. Laundering of hospital staff uniforms at home. J. Hosp. Inf. 2006, 62, 89-93. [CrossRef]

96. Laitala, K.; Boks, C.; Klepp, I.G. Potential for environmental improvements in laundering. Int. J. Consum. Stud. 2011, 35, 254-264. [CrossRef]

97. Tano, E.; Melhus, A. Level of decontamination after washing textiles at 60 degrees c or 70 degrees c followed by tumble drying. Inf. Ecol. Epidemio. 2014, 4, 24314.

98. Brands, B.; Honisch, M.; Wegner, S.; Bockmühl, D.P. The effect of drying processes on the microbial load of laundry brands. Househ. Pers. Care Today 2016, 11, $24-27$.

99. Amichai, B.; Grunwald, M.H.; Davidovici, B.; Shemer, A. Sunlight is said to be the best of disinfectants: The efficacy of sun exposure for reducing fungal contamination in used clothes. Isr. Med. Assoc. J. IMAJ 2014, 16, 431-433. [PubMed]

100. D'Orazio, J.; Jarrett, S.; Amaro-Ortiz, A.; Scott, T. Uv radiation and the skin. Int. J. Mol. Sci. 2013, 14, 12222-12248. [CrossRef]

Publisher's Note: MDPI stays neutral with regard to jurisdictional claims in published maps and institutional affiliations. 